European Journal of Pragmatism and American Philosophy

$|-1 / 2| 2009$

Europe and American Pragmatism: Influences and Interactions

\title{
Lotze and the Classical Pragmatists
}

\section{Christopher Hookway}

\section{(2) OpenEdition}

1 Journals

Electronic version

URL: http://journals.openedition.org/ejpap/965

DOI: 10.4000/ejpap.965

ISSN: 2036-4091

Publisher

Associazione Pragma

\section{Electronic reference}

Christopher Hookway, "Lotze and the Classical Pragmatists », European Journal of Pragmatism and American Philosophy [Online], I-1/2 | 2009, Online since 01 July 2009, connection on 04 May 2019.

URL : http://journals.openedition.org/ejpap/965 ; DOI : 10.4000/ejpap.965

This text was automatically generated on 4 May 2019.

\section{(c) $(1)$}

Author retains copyright and grants the European Journal of Pragmatism and American Philosophy right of first publication with the work simultaneously licensed under a Creative Commons AttributionNonCommercial-NoDerivatives 4.0 International License. 


\title{
Lotze and the Classical Pragmatists
}

\author{
Christopher Hookway
}

1 It has been said that, after the fall of modernism, Hermann Lotze (1817-81) reigned as the single most influential philosopher in Germany, perhaps the world" (Sullivan 2008: 2). ${ }^{1}$ It is now not easy to take such claims about Lotze seriously, and historical surveys of nineteenth century philosophy treat him as a marginal figure, if they mention him at all. Part of the explanation of this change in his standing becomes clear if we accept Sullivan's helpful observation that Lotze was a 'prominent figure within an essentially transitional period' in philosophy (Sullivan 2008: 2-3). It is a mark of his international prominence that the Harvard philosopher George Santayana wrote a PhD dissertation on Lotze's System of Philosophy, Oxford philosopher Bernard Bosanquet edited translations of his major books on Logic and Metaphysics, and he is taken seriously in the writings of Bertrand Russell and Bradley. This paper documents his role in the development of pragmatism. He made a positive contribution to William James's psychology and his writings on pragmatism; and Dewey's instrumentalist approach to logic was developed through critical engagement with Lotze's work.

David Sullivan has described Lotze's work as transitional between post-enlightenment movements such as materialism and romanticism and developments characteristic of early twentieth century philosophies such as the logical analysis of Frege and Russell and Husserl's phenomenology. Often seen as an idealist, he was most plausibly read as preserving a broadly Leibnizian tradition. Lotze's marginal roles in most histories of philosophy can be explained by the fact that he was 'a prominent figure within an essentially transitional period': 'his long shadow was, perhaps, predestined to gradually fade from the scene' (Sullivan 2008).

The description of Lotze as 'transitional' is a clue to some of his relations with pragmatism. According to William James, pragmatism is a mediating philosophy, one that can reconcile the insights of empiricism and rationalism, of materialism and idealism, and of naturalism and phenomenology. These innovations can survive and allow for further development, while Lotze's ideas were more rapidly overcome by new techniques and ideas. The aim of this paper is to describe some of the ways in which the pragmatists learned from, and reacted to, Lotze's work. Peirce was largely disdainful of Lotze's 
contributions but both James and Dewey profited from them in different ways. Dewey exploited his criticisms of Lotze's logic in order to develop his own distinctive approach to the subject, but James found Lotze's work highly congenial and was willing to incorporate his insights in his pragmatism and to his psychological views. ${ }^{2}$

\section{Lotze and James on Psychology}

4 James's writings provide evidence of Lotze's influence ${ }^{3}$ upon his psychological ideas. ${ }^{4}$ Both were eager to put psychology on a scientific footing. We can note a few examples of such influence, noting especially the role of psychological ideas that had a pragmatist character. The first example concerns the origins of James's influential ideas about emotions. Apparently James wrote 'Emotions due to bodily reverberations' on the fly sheet of his copy of Lotze's Medzinische Psychologie (1852), and this is taken to be an explicit acknowledgment of Lotze's influence on James's thought (Myers 1986: 530). A further illustration of this is found in James's chapter on 'The Will' in James's Principles of Psychology. James asserts there that Lotze was the first person to see that muscular exertion is a form of afferent and not of efferent feeling. ${ }^{5}$

5 Another example is provided by James's views about the will. James took from Lotze the idea that 'there is a smooth transition from an idea to behaviour that requires no act of will or effort whatsoever.' He thus endorsed Lotze's views as they are expressed by his saying: 'All the acts of our daily life happen in this wise: our standing up, walking, talking, all this never demands a distinct impulse of the will, but is adequately brought about by the pure flux of thought.' James attached importance to this passage saying that 'to recall this is to avoid the excesses of earlier mentalist psychology which saw the presence of "wilfulness" in every volitional act (James 1983: 103).

6 A third case concerns 'ideo-motor action,' described by James as the principle that 'once an idea occupies the mind it will, unless obstructed, seek expression in action.' This idea is particularly pertinent to pragmatism, suggesting the sort of link between concepts and habits of actions which both Peirce and James saw as fundamental to the doctrine. James credited Lotze together with Charles Renouvier for persuading him of the truth of this view. So there is some evidence that some of the psychological ideas which provided foundations for James's pragmatism were grounded in his reading of Lotze.

\section{Lotze and James's Pragmatism}

7 When we turn to James's 1907 book on Pragmatism we find him often acknowledging Lotze's influence or noting similarities between the views of the two philosophers. And these similarities concern doctrines that are integral to James's pragmatism. The first of these passages is in lecture VII on 'Pragmatism and Humanism.' James is defending his account of the difference between pragmatism and rationalism, and he explains that 'for rationalism, reality is ready made and complete from all eternity, while for the pragmatist it is still in the making, and awaits part of its complexion from the future' (James 1907: 123). For the rationalist, 'the universe is absolutely secure, on the other it is still pursuing its adventures.' 
James links this important pragmatist doctrine to a 'deep suggestion' that had been made by Lotze, when he criticizes a naïve and mistaken conception of reality which we naturally assume but which reflects the rationalistic outlook

Reality, we naturally think, stands ready-made and complete, and our intellects supervene with the one simple duty of describing it as it is already. (James 1907: 123)

Lotze's proposed alternative is that 'our descriptions' may 'themselves be additions to reality.' Indeed, he suggests that the 'previous reality' does not exists in order for us to obtain knowledge of it which presents just what was there already. Instead, its function is to

'[stimulate] our minds to such additions as shall enhance the universe's total value.' It is not surprising that James identifies this with 'our pragmatistic conception.' The world is 'malleable,' being transformed by our attempts to know it. James cites this view as adding to our 'dignity and our responsibility as thinkers' and remarks upon how the Italian pragmatist, Papini, is inspired by 'the view it opens of man's divinely-creative functions.' It is in harmony with Peirce's claim that our contributions to inquiry enable us to make our contribution to the process of creation. (James 1907: 123)

For all pragmatists, the content of a concept is explained in terms of how things behave in virtue of falling under that concept. As James puts it, the 'pragmatic method' involves interpreting notions by tracing [their] 'practical consequences.' Again in Pragmatism, James asks: 'Is it not time to repeat what Lotze said of substances, that to act like one is to be one?' (James 1909: 64). A similar point is made in Essays on Radical Empiricism, where James endorses Lotze's claim that 'to be an entity all that is necessary is to gelten as an entity, to operate, or be felt, experienced, or in anyway realized, as such' and recognizes that his position is in harmony with Lotze's requirement (James 1912: 85).

\section{Pragmatists and Lotze's Logic}

11 So far we have seen evidence that Lotze's views about mind and reality have much in common with the kind of pragmatism defended by William James. When we turn to his views on Logic, things are different and appear to be subject to pragmatist criticism. Dewey used Lotze's Logik in courses on 'The Logic of scientific methods' at Michigan in 1890 and 'Theory of Logic' at Chicago in 1899-1900 (Shook 2000: 188-9), so it is understandable that Lotze's approach to logic became his target when he was developing his own ideas.

In 1903, John Dewey published Studies in Logical Theory, a collection of papers by himself and his students at the University of Chicago which presented what he offered as a new approach to logic. Dewey's own four contributions all have as their running title 'Thought-and its subject-matter,' and the first carries the title 'The general problem of logical theory. ${ }^{16}$ The aim of his chapter is to explain how the need for a logical theory arises, to contrast two contrasting approaches to the nature of logical theory, and to make a case for favouring one of the two. The conception of logic that he criticized - in each of the four papers - was to be found in Herman Lotze's Logik. Dewey developed his own conception of logic by criticizing Lotze's influential views. Where James saw Lotze as a source of valuable ideas which were compatible with pragmatism, Dewey valued Lotze as the author of views that should be rejected and he thought that criticizing them will be a source of positive insights. ${ }^{7}$ 

careful, serious inquirer,' this faint praise becoming fainter when he adds that 'he was never a thinker of great subtilty' (sic). Commenting on Dewey's book, he remarked that 'I regretted your making everything turn on Lotze, as if he were a Hume' and turned the screw by remarking that Lotze was 'rather small game for [Dewey]' and is now 'so entirely left behind, that I thought you might have left his doctrine to be disposed of by lesser thinkers. Where Dewey saw Lotze as a source of instructive mistakes, Peirce denied him even that merit. of thought to its empirical antecedents and to its consequent, truth, and the relation of truth and reality' (1903: 1). And he reminds us that 'from the naïve point of view,' such questions present us with no difficulty since we think about 'anything and everything,' often in response to a particular practical need. Dewey suggests that the naive standpoint's account of reasoning is that 'thinking is an activity which we perform at specific need, just as at other need we engage in other kinds of activity.' Moreover, its 'material' is 'anything in the wide universe which seems to be relevant to this need.' The naïve point of view can respond to such issues as arise without developing the sort of general theory that is to be found in logic books. We look for a theory only in special circumstances, notably when 'circumstances require the act of thinking and nevertheless impede clear and coherent thinking in detail; or when they occasion thought and then prevent the results of thinking from exercising directive influence upon the immediate concerns of life' (1903: 4). In other words, we only look for a theory of thinking when our practice of thinking and our various cognitive and practical presents us with problems, when our practice loses its familiar 'organic character.'

When this occurs, and we seek a logical theory, that we find ourselves asking questions that are significantly different from those that are addressed in practical deliberations and scientific research. When we seek a theory of reasoning, we want something general. The naïve standpoint assumes that every inquiry or process of reasoning is concerned with specific purposes and specific circumstances. When thinkers like Lotze raise questions about 'the relation of truth and reality,' for example, they seem to abstract from all that is particular and specific in our reasoning and deliberations. The question that divides Lotze and Dewey concerns just how abstract our logical theories need to be.

Lötze's treatise on Logic was tellingly divided into three parts: 'Pure logic, 'Applied logic,' and 'On Knowledge (Methodology).' Logic could be applied to the solution of problems about how we should conduct inquiries and about the evaluation of beliefs. But pure logic said nothing about psychological states such as beliefs or activities such as inquiries; instead, it is devoted to 'thought in general and those universal forms and principle of thought which hold good everywhere, both in judging of reality and in weighing possibility, irrespective of any difference in the objects' (Lötze 1888: 10-1). The three sections of his discussion of pure logic are devoted to concepts, judgments, and inferences respectively. And in classifying the different kinds of concept, judgment, and inference, it treats them as 'ideal forms, which give the matter of our ideas, if we succeed in arranging it under them, its true logical setting' (ibid.: 11). Applying these ideal forms to concrete investigations with specific subject matters is a messy business: the peculiarities of particular subject matters 'offer resistance to this arrangement' under the ideal forms. And 'applied logic is concerned with those methods of investigation which obviate these defects. It considers hindrances and the devices by which they may be 
overcome; and it must sacrifice the love of systematisation to considerations of utility, and select what the experience of science has so far shown to be important and fruitful' (ibid.).

Lötze's approach to logic thus has a two stage character. Pure logic provides us with $a$ priori knowledge of ideal forms that reveal the nature of concepts, judgements, and inferences. These forms can then, with difficulty, be applied to concrete cases. In identifying these ideal forms, it abstracts from all empirical information about particular investigations and particular subject matters. We need such information when we apply logic to provide guidance in our reasoning and investigations; but it is of no relevance to the study of the ideal subject matter of pure logic. It is thus a mark of the purity of logic that it is independent of psychology (1888: 10): when doing pure logic we can ignore the psychological processes that are presumably involved in ordinary reasoning. Logic's starting point is simply that 'between combinations of ideas, however they may have originated, there is a difference of truth and untruth, and that there are forms to which these combinations ought to answer and laws which they ought to obey' (Lotze 1888: 8). Information about the genesis of our ideas is irrelevant to pure logic.

In order to avoid relativism and scepticism, he thought, we need necessary laws of thought. Our knowledge of such laws is grounded in 'intuition,' a faculty that reveals to us self-evident truths. Indeed, logic and other areas of knowledge rely upon axioms of whichwe have self-evident knowledge. In constructing logical concepts and identifying logic laws, we can rely upon a system of categories (roughly of things, properties and relations), which is reflected in the grammatical categories of 'substantive,' 'adjective' and 'verb.' This presumably ensures that the logical laws will be abstract, as general as is possible, and minimally dependent upon the specificities of particular thoughts and inquiries.

19 This provides the context for Dewey's defense of his view of logic. He tells us that 'the very nature of logical theory as a generalization of the reflective process must of necessity disregard the matter of particular conditions and particular results as irrelevant.' So long as logic studies the relations of 'thought as such' to 'reality as such,' it seeks abstract and very general formulations. This is what Dewey finds in Lotze who holds that 'pure logic' is concerned with 'universal forms and principles of thought which hold good everywhere both in judging reality and in weighing possibility, irrespective of any difference in the objects' (1903: 6).

20 Logical theory is concerned with 'thought as such - thought at large or in general.' And it asks 'how far the most complete structure of thought [...] can claim to be an adequate account of that which we seem compelled to assume as the object and occasion of our ideas' (Lotze 1988: 9). It provides a general abstract account of thought, truth, reference etc, and it engages with our ordinary practical and scientific deliberations by, like any abstract scientific theory, being applied to concrete circumstances. But these circumstances, and the differences between the objects of different thoughts, can be safely ignored while we are doing pure logic. So logic achieves generality by dealing with universal abstract laws and principles that are binding upon all possible thought and inference. These can be applied to particular cases, and this can help us in dealing with problems. 'The entire procedure of practical deliberation and of concrete scientific research' is thus irrelevant to the project of pure logical theory.

21 Dewey describes this sort of approach to logic as 'epistemological,' because it entails that the fundamental problem of logical theory was to explain 'the eternal nature of thought 
and its eternal validity in relation to an eternal reality' (Dewey 1916: 92). As Dykhuizen put it, the kind of logic that Dewey rejects holds that 'the function of thought is to represent reality and that the truth of an idea depends upon how faithfully it does this (1973: 84). The justification for describing such theories as 'epistemological' is that once we give a very abstract account of thought and reasoning, one which ignores the specificities of particular episodes of reasoning, we find ourselves facing sceptical questions: what reason have we to think that processes if thought described in these abstract terms can provide us with knowledge of reality? Such logics force us to confront fundamental epistemological problems. These concern the relations between thought-assuch and reality-as-such. This becomes clear in Dewey's second essay, where he describes Lötze's account of the materials of inquiry and the circumstances in which we inquiry. It is indeed cast in very abstract terms. The 'ultimate material antecedents of thought consist in impressions, which are due to external objects as stimuli. Taken in themselves, these impressions are mere psychical states or events': an impression is nothing but 'a state of our consciousness, a mood of ourselves.' Inquirers then examine patterns which are sometimes 'coincident' and at other times 'coherent'; and the aim of reasoning is to 'recover and confirm the coherent, the really connected, adding to its reinstatement an accessory justifying notion of the real ground of coherence, while it eliminates the coincident as such' (1903: 27ff). This ignores all that is specific to any particular inquiry but, at the same time, captures a common form that fits all. Dewey is scornful of Lötze's attempt to somehow get from the impression, which is subjective, to its real ground.

It is important here that formal logic did not have a major role in Lotze's system of pure logic (Lotze 1888: 208ff). In fact, he complained that contemporary developments in Boolean algebra, for example, did little more than give us a notation that offered an unhelpful restatement of what we all knew already. Rather than being concerned with the properties of arguments or the logical forms of propositions, Lotze's logic was concerned with the a priori principles that made judgement possible. This still left room for the study of the structure of thoughts and propositions. Lotze relied upon studies of the grammatical structures of sentences to identify fundamental categories that our reflected in the judgments we make. He relied upon a grammatical classification of expressions into substantives, adjectives and verbs, to identify a categorial classification of the elements of thought into things, properties and relations.

Lotze thought that the principles used in logic are knowable a priori, that they are expressed in necessary truths, and that without them, we have no answer to scepticism and relativism. They take the form of a system of axioms, and when we ask how we are justified in accepting the axioms, the answer is that they are self-evident. At this point, Lotze's distinction between the genetic or psychological and the logical becomes important. Presumably, in constructing these laws, Lotze would have to reflect upon our ordinary practices of thinking and reflecting; the subjective psychological processes involved in arriving at them may be complex. But to regard these reflections and processes as relevant to the justification of these laws would be to succumb to a psychologistic error. Once these processes have been completed, the normative standing of our acceptance of these laws is determined by their self-evidence. There is nothing further to say about why we are right to accept them and how they are self-evident. Lotze's general account of justification is broadly coherentist: in ordinary investigations, we begin with our simple subjective sensations, we recognize that the patterns among them can be distinguished into those that are 'coincident' and those that display 
coherence. When we think, we try to carry out procedures designed to identify and preserve coherence. Once we try to use these ideas to relate 'though-as-such' to 'realityas-such,' it becomes open to charges of vicious circularity. Lotze's response that 'The circle is inevitable, so we had better perpetrate it with our eyes open' does not inspire confidence (Lotze 1880: 451). ${ }^{8}$

Dewey suggests that we should consider a different way of 'stating the problem of logical theory.' The key idea is that, while a general theory will have to abstract from 'much of the specific material and contents of thought situations of daily life and critical science,' it can still identify 'certain specific conditions and factors, and aim to bring them to clear consciousness.' It seems to be an empirical investigation which tries to identify the features that are common to circumstances that prompt inquiry, to 'show how typical features in specific circumstances of thought call out to diverse typical modes of thoughreaction,' and it can 'attempt to state the nature of the specific consequences in which thought fulfils its career' (Dewey 1903: 7). We begin with particular cases, and then identify patterns involving kinds of particular cases whose laws can be used to deal with the problems that first give rise to the search for a logic theory.

So the big difference between Lotzean logic and Dewey's logic is that the former seeks complete generality, it seeks to abstract from all and any of the specific features of reasoning and find laws that govern all possible kinds of reasoning and inquiry. Dewey seeks a kind of generality which is intermediate between this complete generality and a study of thought which focuses on the particular case and their idiosyncrasies. Awareness of the problems that give rise to the search for a logical theory can guide us in formulating laws governing particular kinds of inquiry, or inquiries that share distinctive salient features. So we develop a logical theory which already incorporates the classifications we need to use when trying to exercise self-control over our reflection and inquiry. Logical theory no longer has a two stage character: we don't construct a general theory using a vocabulary which is not constructed with an eye to how we want to describe inquiry and reflection. Rather our logical theory already uses the vocabulary of the theory of inquiry and there is a continuity between our practice of inquiry and the developing of a logical theory that can guide it. It is relevant to this that Dewey describes his approach as one of 'instrumental logic.' This is a type of logic which 'deals with thinking as a specific procedure relative to a specific antecedent situation and to a subsequent fulfilment' (1903: 8). From this perspective, 'an attempt to discuss the antecedents, data, forms, and objective of thought, apart from reference to particular position occupied and particular part played in the growth of experience is to reach results which are not so much true or false as they are radically meaningless - because they are considered apart from limits' (1903: 8). To think about the aims and conditions of thought 'apart from the limits of a historic or developing situation, is the essence of a metaphysical procedure - in the sense of metaphysics which makes a gulf between it and science' (1903: 8-9).

So Lotze employs a distinction between pure logic and applied logic, the former taking the form of a framework of a priori knowable necessary truths or principles. Dewey rejects that distinction; we can use our logical standards to criticize arguments and beliefs without making use of a logical theory with these properties. The use of logic lies in guiding reflection in dealing with concrete problems, and the role of logical theory is determined by what is needed for our practice of reasoning. Lotze is associated with a 
kind of rationalist intellectualism which James would recognize as the enemy of pragmatism.

A schematic comparison of Lotze, Peirce, and James is useful here, and it will help to explain Peirce's disdain for Lotze's work. Peirce would be in agreement with Lotze about two important points: both hold to a distinction between pure and applied logic; and both deny the relevance of psychology and other natural sciences to pure (or, in Peirce's term, 'normative') logic. Dewey would disagree with them on both points. Theory in logic is less abstract and all encompassing than Lotze or Peirce would accept, both of whom think that that logical theory must deal with 'all possible thoughts.' And he would welcome a 'rapprochement' between logic and psychology and natural history. Dewey's pragmatism is inseparable from his rejection of Lotze's pure logic: his rationalism is at odds with pragmatist ideas. But Peirce thinks that his form of normative or pure logic is compatible with pragmatism. This is because the achievements of which he is most proud are contributions to formal logic. According to Peirce, the epistemology of formal disciplines need not appeal to suspect concepts such as 'self-evidence.'

\section{Conclusion}

It is clear that, in very different ways, the philosophical ideas of both James and Dewey were influenced by their knowledge of Lotze's writings. This is itself an acknowledgment of Lotze's prominent position in the philosophical world of the years either side of 1900 . This is further illustration of the role of European thought in fuelling pragmatism. My conclusion is a modest one, that a better understanding of this part of the intellectual context of pragmatism probably has more of offer to our understanding of James and Dewey than is currently supposed.

\section{BIBLIOGRAPHY}

DEWEY J., (1903), Studies in Logical Theory, University of Chicago.

DEWEY J., (1916), Essays in Experimental Logic, New York, Dover.

DYKHUIZEN G., (1973), The Life and Mind of John Dewey, Carbondale, Southern Illinois University

Press.

HATfield G., (2003), "Psychology Old and New," in Baldwin (ed) The Cambridge History of Philosophy: 1870-1945, Cambridge, Cambridge University Press, 93-106.

JAMES W., (1890), Principles of Psychology, New York, Dover, 1950.

JAMES W., (1907), Pragmatism, Cambridge, MA, Harvard University Press, 1975

JAMES W., (1909), The Meaning of Truth, Cambridge, MA, Harvard University Press, 1978.

JAMES W., (1912), Essays on Radical Empiricism, Cambridge, MA, Harvard University Press, 1977.

JAMEs W., (1983), Essays in Psychology, Cambridge, MA, Harvard University Press, 1983. 
KRAUSHAAR O., (1936), “Lotze's Influence on the Psychology of William James," Psychological Review XLIII, 235-57

KRAUSHAAR O., (1938), “What James's Philosophical Orientation owed to Lotze," Philosophical Review XLVII, 517-26.

KRAUSHAAR O., (1939), “Lotze as a Factor in the Development of James's Radical Empiricism and Pluralism," Philosophical Review XLVIII, 455-71

KRAUSHAAR O., (1940), “Lotze's Influence on the Pragmatism and Practical Philosophy of William James," Journal of the History of Ideas, vol. 1, 439-58

LOTZE H., (1852), Medzinische Psychologie, Leipzig, Weidmann.

LOTZE H., (1880), "Philosophy in the last Forty Years: First Article," in Kleine Schriften, v. 3.

LOTZE H., (1888), Logic (second edition, translation edited by Bernard Bosanquet), Oxford, Clarendon Press (First German edition 1874, second edition 1880).

MYERS G. E., (1986), William James: His Thought and Life, New Haven, CT, Yale University Press.

PEIRCE C. S., (1958), Collected Papers of Charles Sanders Peirce vol. 8, ed. A. Burks, Cambridge, MA, Harvard University Press. References give to 'CP' followed by volume number and section number (for example CP8.244).

SHоOK J., (2000), Dewey's Empirical Theory of Knowledge and Reality, Nashville Tennessee, Vanderbilt University Press.

SLEEPER R. W., (1986), The Necessity of Pragmatism: John Dewey's Conception of Philosophy, New Haven CT, Yale University Press.

SUlLIVAn D., (2008), “Hermann Lotze," The Stanford Encyclopedia of Philosophy (Winter 2008 Edition), Edward N. Zalta (ed.), URL= [plato.stanford.edu/archives/win2008/entries/hermann-lotze/].

\section{NOTES}

1. The quoted passage is from David Sullivan's valuable article on Lotze in the Stanford Encyclopedia of Philosophy. The passage quoted here is not an idiosyncratic remark by a single scholar. Gary Hatfield holds that between 1850 and 1875, Lotze was probably 'the foremost German academic philosopher and psychologist' (Hatfield 2003: 98).

2. Lotze also had a role in the development of analytical philosophy. Frege attended his lectures on logic and studied his Logik. Hans Sluga argues that Frege's ideas are deeply indebted to those of Lotze (1980: 5) but Michael Dummett has respnded that this claim rests upon a distorted understanding of the history of philosophy. For our purposes we need to note one important issue on which they disagreed: Lotze rejected the formalization of logic (1988: 208ff).

3. There is relatively little contemporary literature on the relations between the thought of Lotze and James, probably because of diminishing interest in Lotze. Otto Kraushaar wrote four papers between 1936 and 1940 which are listed in the references.

4. For my purposes of this paper, I am more concerned with how the pragmatists responded to Lotze, and what they took him to be saying, than with issues about whether they understood him correctly. This is why my claims about Lotze's influence upon James's views are generally based upon James's testimony.

5. Dewey appeals to Lotze's account of emotions in his 1916 paper 'Logic of judgments of practice' in defence of a pragmatist account of value judgments. He attributes to Lotze the view that 
emotions, 'as involving pleasure and pain' are 'organs of value judgments' or 'appreciations of worth' (Dewey, 1916: 351).

6. The subtitles of the other three papers are 'The antecedents and stimuli of thinking,' 'Data and meanings' and 'The objects of thought.' All four papers were reprinted, without the running title as the first four chapters of Dewey's Essays in Experimental Logic (1916).

7. Ralph Sleeper makes the interesting suggestion that Dewey's real target was 'an account of logic that would avoid both Peirce's formalism and James's psychologism.' His use of Lotze came from the latter's attack on the psychologism associated with empiricists such as Mill. He wanted to show that a more radical version of empiricism might enable him to escape the a priori (Sleeper 1986: 64-5).

8. The passage in which this quotation occurs is given at greater length by Sullivan (2008: 12).

9. In fact, Dewey suggests that someone like Lotze would recognize the value of instrumental logic,' but would treat it as an application of pure logic, as something subordinate to fundamental logical theory (Dewey 1903: 8). 